\title{
Idiopathic congenital hypothyroidism
}

\author{
INSERM
}

\section{Source}

INSERM. (1999). Orphanet: an online rare disease and orphan drug data base. Idiopathic congenital hypothyroidism. ORPHA:95717

Idiopathic congenital hypothyroidism is a type of primary congenital hypothyroidism (see this term) whose cause and prevalence are unknown. 